\title{
Tracheobronchopathia osteochondroplastica: innocuous but distressing
}

\author{
T G Ranganath, ${ }^{1}$ Sanjib Mallick, ${ }^{2}$ S Mamatha, ${ }^{2}$ Rahul Srivastava ${ }^{3}$
}

${ }^{1}$ Department of Pulmonary Medicine, Sanjay Gandhi Postgraduate Institute of Medical Sciences, Lucknow, Uttar Pradesh, India ${ }^{2}$ Sanjay Gandhi Postgraduate Institute of Medical Sciences, Lucknow, Uttar Pradesh, India ${ }^{3}$ Department of Pulmonary Medicine, CSM Medical University, Lucknow, Lucknow, Uttar Pradesh, India

Correspondence to Dr T G Ranganath, ranganathtg@gmail.com
To cite: Ranganath $\mathrm{TG}$, Mallick S, Mamatha S, et al. BMJ Case Rep Published online: [please include Day Month Yearl doi:10.1136/ bcr-2013-010435

\section{DESCRIPTION}

A 60-year-old non-smoker woman presented with dry cough, breathlessness on exertion and multiple episodes of haemoptysis from past 20 years. She reported nausea and vomiting since 20 days and jaundice since 15 days. She had received multiple courses of antibiotics and antitussives, syrups like levodropropizine $30 \mathrm{mg} / 5 \mathrm{~mL}$, dextromethorphan $10 \mathrm{mg} / 5 \mathrm{~mL}$ due to symptoms mimicking chronic pharyngitis. Antitubercular treatment (ATT) was given due to haemoptysis on empirical basis from past 5 months as her mantoux test had shown an induration of $15 \mathrm{~mm}$. Her clinical examination was within normal limit. Multiple chest X-rays taken over the years were also normal. Her liver function test (LFT) was as follows, serum total bilirubin: $2.1 \mathrm{mg} / \mathrm{dL}$, aspartate aminotransferase: $410 \mathrm{U} / \mathrm{L}$, alanine aminotransferase: $610 \mathrm{U} / \mathrm{L}$, alkaline phosphatase: $180 \mathrm{U} / \mathrm{L}$. ATT was stopped due to deranged liver function and as there
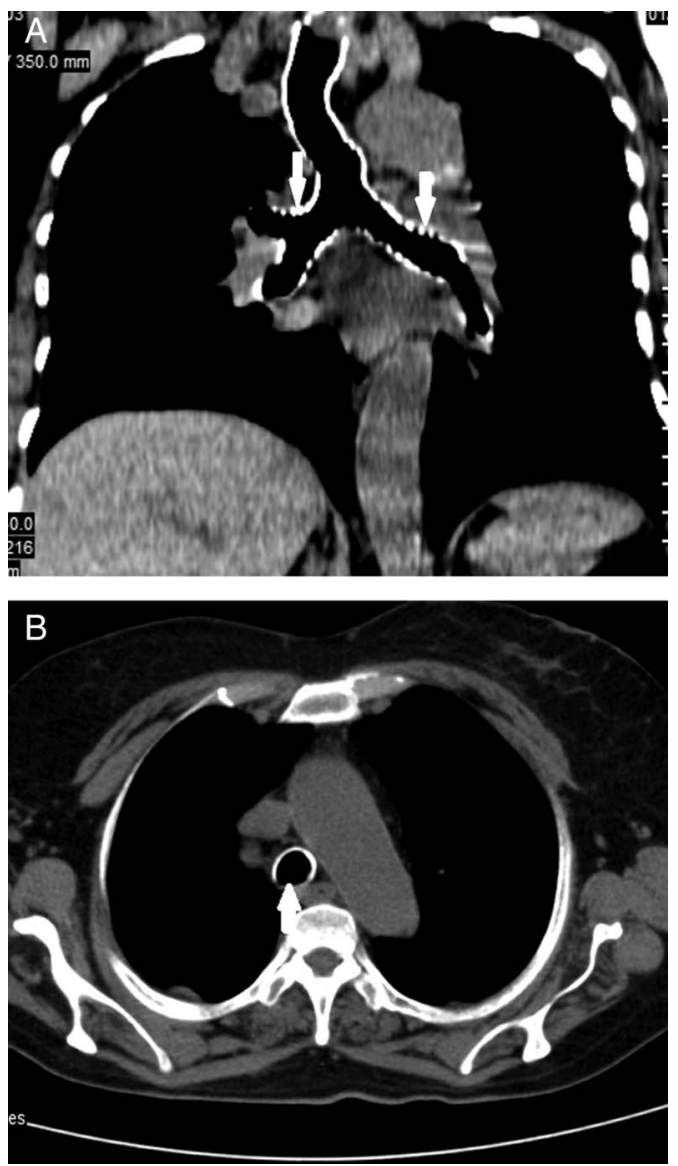

Figure 1 (A) High-resolution CT thorax showing calcification along the trachea and major bronchi. Submucosal nodular pattern can also be seen (arrows). (B) High-resolution CT thorax showing typical sparing of posterior wall (arrow). was no evidence of tuberculosis. Her LFT returned to normal after 10 days. Sputum for acid-fast bacilli and Mycobacterium tuberculosis cultures were negative on two consecutive occasions. Spirometry was suggestive of mild obstructive airway disease. High-resolution CT of thorax confirmed the diagnosis, which lead to the diagnosis in our patient (figure 1). Her symptom of breathlessness improved with inhaled formoterol and budesonide. The patient was asked to follow-up in the outpatient department once in 6 months and also if haemoptysis occurred in between. Bronchoscopy was not performed as the patient did not give consent for the procedure. Tracheobronchopathia osteochondroplastica (TO) is a rare disorder of unknown aetiology. Cough not responding to usual medical treatment is the most common symptom. Recurrent haemoptysis and breathlessness are the other symptoms. Wheezing occurs in patients with airway obstruction. ${ }^{1}$ Calcification of major airways with sparing of the posterior wall and dense submucosal nodules can be seen in CT scan. ${ }^{1}$ Direct visualisation at bronchoscopy usually confirms the diagnosis. TO needs no specific treatment; surgery may be warranted in patients with airway obstruction. ${ }^{1}$

\section{Learning points}

Haemoptysis is not always due to tuberculosis even in high burden countries.

- Always confirm tuberculosis bacteriologically or histopathologically.

- Empirical antitubercular treatment (ATT) exposes patients to adverse effects.

- Always look for alternative diagnosis in patients not responding on ATT.

- Higher investigation like high-resolution CT should be used appropriately.

Acknowledgements The authors acknowledges Dr Pratibha Sharma MD for giving all the necessary support in making the manuscript and literature review.

Contributors TGR diagnosed the case and also approved the final manuscript. SM collected the radiological images and did the literature search. SM and RS were involved in writing and editing the manuscript.

Competing interests None.

Patient consent Obtained.

Provenance and peer review Not commissioned; externally pee reviewed.

\section{REFERENCE}

1 Leske V, Lazor R, Coetmeur D, et al. Tracheobronchopathia osteochondroplastica: a study of 41 patients. Medicine 2001;80:378-90. 


\section{Images in...}

Copyright 2013 BMJ Publishing Group. All rights reserved. For permission to reuse any of this content visit http://group.bmj.com/group/rights-licensing/permissions.

BMJ Case Report Fellows may re-use this article for personal use and teaching without any further permission.

Become a Fellow of BMJ Case Reports today and you can:

- Submit as many cases as you like

- Enjoy fast sympathetic peer review and rapid publication of accepted articles

- Access all the published articles

- Re-use any of the published material for personal use and teaching without further permission

For information on Institutional Fellowships contact consortiasales@bmjgroup.com

Visit casereports.bmj.com for more articles like this and to become a Fellow 